кислоты рассчитывают, как процентное отношение количества полученной азотной кислоты к тому количеству, которое должно получиться теоретически по уравнению реакции [4].

\title{
Анализ работы
}

Цифровые данные оформить в виде таблицы.

\begin{tabular}{|l|l|}
\hline Концентрация аммиака (в \%) & \\
\hline Поступило аммиака на окисление (в 2) & \\
\hline Кислоты (в 2) & \\
\hline $\begin{array}{l}\text { Выход кислоты (в \%): 1) начальная; 2) } \\
\text { конечная; 3) получено; 4) долюсно получиться }\end{array}$ & \\
\hline
\end{tabular}

\section{III. Заключительная часть}

Учитель подводит итог урока. Сегодня мы получили водный раствор азотной кислоты, повторили технику безопасности.

Домашнее задание. Оформить ход лабораторной работы в тетради и выполнить письменно в тетради задания:

1) Чем объяснить; что при многократном поглощении оксида азота (IV) водой в присутствии кислорода в конечном итоге получается азотная кислота, а при поглощении оксида азота (IV) раствором щелочи получается смесь нитратов и нитритов.

2) Сколько теоретически должно получиться азотной кислоты ( $\rho=1,4$

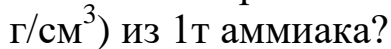

3) На синтез поступило 568кг аммиака, из которого получено 2280л азотной кислоты, содержащей 62,23\%. Определите выход азотной кислоты $\left(\rho=1,390\right.$ г/ $\left.\mathrm{cm}^{3}\right)$.

Вывод: Лабораторные работы обеспечивают связь теории с практикой, развивают самостоятельность и способность к постановке и проведению экспериментов, пониманию и интерпретации фактов, к анализу явлений и синтезу, к оценке полученной информации, применению знаний на практике. На уровне учебных дисциплин лабораторные работы обеспечивают знакомство с оборудованием, приборами, средствами измерения, с методикой исследования, пополняя знания фактами, они позволяют определить и проверить теоретические зависимости.

$$
* * *
$$

1. Дьяченко В.К. Роль лабораторных работ в учебном процессе. /В.К. Дьяченко. - М.: Просвещение, 2005. - C.226.

2. Купетов А.М. и др. Общая химическая технология. - М.: Высшая школа, 1985.

3. Общая химическая технология. Под ред. А.Г. Амелина. - М.: Химия, 1977.

4. Соколов Р.С. Химическая технология: Учеб. Пособие для студ. Высш. Учеб. Заведений: 2т. - М.: Гумат. Изд. Центр ВЛАДОС, 2003.

Зайцева А.И., Закомурная Д.А.

Лабораторное занятие по теме «Химико-экологические проблемы атмосферы» ФГОБ ВО Самарский государственный соичильно-педагогический университет doi: $10.18411 / \mathrm{j}-05-2020-333$

(Россия, Самара)

idsp: ljournal-05-2020-333

Научный руководитель Нелюбина Е.Г.

\section{Аннотация}

В статье приводится лабораторное занятие по теме: химико-экологические проблемы атмосферы, где используются методы, такие как: словесные, практические (распознавание и определение объектов в форме лабораторной работы). 
Ключевые слова: атмосфера, вредные вещества, оксид азота, углерода, экологические проблемы.

Abstract

The article provides a laboratory lesson on the topic: chemical and environmental problems of the atmosphere, where methods are used, such as: verbal, practical (recognition and determination of objects in the form of laboratory work). problems.

Keywords: atmosphere, harmful substances, nitric oxide, carbon, environmental

Актуальность темы нашего исследования акцентируется в реализации развития интереса школьников к химико-экологической предметной области познания.

Данная лабораторная работа имеет исследовательский характер. Учитель может сам решать, как провести это занятие.

В конце лабораторной, мы бы хотели порекомендовать оформление статьи по результатам проведённой работы, а так же представить список возможных экологических решений. Ниже представлен ход занятия.

Принимая во внимание близость к автомагистрали жилых и общественных зданий, обязательно сделать вывод об экологической обстановке в районе исследуемого вами участка автомагистрали.

Учитель: Автотранспорт является одним из основных загрязнителей атмосферы оксидами азота $\mathrm{NO}_{\mathrm{x}}$ (смесью выхлопных газов $\mathrm{NO}$ и $\mathrm{NO}_{2}$ ) и угарным газом (оксид углерода (II), CO), содержащихся в выхлопных газах. Доля транспортного загрязнения воздуха составляет более $60 \%$ по СО и более $50 \%$ по $\mathrm{NO}_{x}$ от общего загрязнения атмосферы этими газами.

Выбросы вредных веществ от автотранспорта характеризуются количеством основных загрязнителей воздуха, попадающих в атмосферу из выхлопных (отработанных) газов за определенный промежуток времени.

Учитель: нам необходимо провести «Расчетная оценка количества выбросов вредных веществ в атмосферу от автотранспорта».

\section{План работы:}

1. Подсчет количество автотранспорта и общий путь, пройденный автомобилями каждого типа за 1 час (заполнить табл.1).

2. Заполнение таблицы 2. Общее количество топлива каждого вида автомобиля.

3. Заполнение табл. 3.

4. Обработка результатов по табл. 4.

Выполнение работы (по группам из 3-4-х учащихся)

1. Выберите участок автотрассы длиной 0,5 - 1 км, имеющий хороший обзор.

2. Определите длину участка и ширину дороги на данном участке.

3. Определите количество единиц автотранспорта, проходящего по участку в какой-либо период времени в течение 20 минут.

4. Рассчитайте количество автотранспорта проходящего по участку за 1 час и общий путь, пройденный за это время (таблица 1).

Таблийа 1

Количество автотранспорта и общий путь, пройденный автомобилями каждого типа

\begin{tabular}{|c|c|c|c|}
\hline Тип автотранспорта & $\begin{array}{c}\text { Количество за } 20 \\
\text { минут, шт. }\end{array}$ & За час, Ni, шт & $\begin{array}{c}\text { Общий путь за } \\
1 \text { час, L, км }\end{array}$ \\
\hline Легковой автомобиль & & & \\
\hline Грузовой автомобиль & & & \\
\hline Автобус & & & \\
\hline Дизельный грузовой автомобиль & & & \\
\hline
\end{tabular}


Общий путь, пройденный выявленным количеством автомобилей каждого типа за 1 час (L, км) рассчитывается по формуле: $\mathrm{Li}=\mathrm{Ni} \cdot 1$, где

$\mathrm{N}$ - количество автомобилей каждого типа за 1 час; i- обозначение типа автотранспорта? 1 - длина участка, км. Заполните таблицу 2. Определите общее количество сожженного топлива каждого вида $\left(\sum \mathrm{Q}\right)$. Количество топлива $(\mathrm{Qi}, \pi)$ разного вида, сжигаемого при этом двигателями автомашин, рассчитывается по формуле: $\mathrm{Qi}=\mathrm{Li} \cdot \mathrm{Yi}$ (Значения Yi возьмите из таблицы 2)

Таблийа 2

\begin{tabular}{|c|c|c|}
\hline Тип автотранспорта & $\begin{array}{c}\text { Средние нормы } \\
\text { расхода топлива (л на } \\
100 \text { км) }\end{array}$ & $\begin{array}{c}\text { Удельный расход топлива Үј } \\
\text { (л на км) }\end{array}$ \\
\hline Легковой автомобиль & $11-13$ & $0,11-0,13$ \\
\hline Грузовой автомобиль & $29-33$ & $0,29-0,33$ \\
\hline Автобус & $41-44$ & $0,41-0,44$ \\
\hline Дизельный грузовой автомобиль & $31-34$ & $0,31-0,34$ \\
\hline
\end{tabular}

Таблица 3

Общее количество топлива каждого вида (заполнить)

\begin{tabular}{|c|c|c|c|}
\hline \multirow{2}{*}{ Тип автотранспорта } & \multirow{2}{*}{$\mathrm{Li}$} & \multicolumn{2}{|c|}{$\mathrm{Qi}$, в том числе } \\
\cline { 3 - 4 } & & & бензин \\
\hline Легковой автомобиль & & & \\
\hline Грузовой автомобиль & & & \\
\hline Автобус & & & \\
\hline Дизельный грузовой автомобиль & & & \\
\hline & Bсего $\sum \mathrm{Q}$ & & \\
\hline
\end{tabular}

Заполните таблицу 4. Рассчитайте количество выделившихся вредных веществ в литрах при нормальных условиях по каждому виду топлива и всего. Количество вредных веществ, выделяемых при сгорании каждого вида топлива (в литрах) рассчитывается с помощью коэффициента К (таблица 2).

Таблица 4

Количество вредных веществ по каждому виду топлива (заполнить)

\begin{tabular}{|c|c|c|c|c|}
\hline \multirow{2}{*}{ Вид топлива } & \multirow{2}{*}{$\sum \mathrm{Q}$,л } & \multicolumn{3}{|c|}{ Количество вредных веществ, Л } \\
\cline { 3 - 5 } & & $\mathrm{CO}$ & $\begin{array}{r}\text { Углеводороды } \\
\left(\text { пентан } \mathrm{C}_{5} \mathrm{H}_{12}\right.\end{array}$ & $\mathrm{NO}_{2}$ \\
\hline Бензин & & & & \\
\hline Дизельное топливо & & & & \\
\hline & Всего(V),л & & & \\
\hline
\end{tabular}

\section{Обработка результатов и выводы.}

Рассчитайте массу выделившихся вредных веществ для обеспечения санитарнодопустимых условий атмосферы.

Результаты запишите в таблицу 5.

Таблий 5

\begin{tabular}{|l|l|l|c|}
\hline Вид вредного вещества & Количество, л & Масса,m г & $\begin{array}{c}\text { Значение ПДК мгџм } \\
\text { (Значение ПДК в табличе }\end{array}$ \\
\hline $\mathrm{CO}$ & & & 6) \\
\hline $\mathrm{У}_{\text {глеводороды }}$ & & & \\
\hline $\mathrm{NO}_{2}$ & & & \\
\hline
\end{tabular}

Масса выделившихся вредных веществ $(\mathrm{m}, \Gamma)$ рассчитывается по формуле: $\mathbf{m}=\mathbf{V} \cdot \mathbf{M} / \mathbf{2 2 , 4}$ где $\mathrm{V}$ - объем в литрах из табл.4, M - молекулярная масса, грамм/моль 
$(\mathrm{C}=12 ; \mathrm{N}=14 ; \mathrm{O}=16 ; \mathrm{H}=1)$; число 22,4 - константа (объем Авогадро) - объем 1 моль газа при н.у., л/моль.

Сравнить показания, которые получились с таблицей 6 (сравнение написать в выводе по классу опасности).

Таблийа 6

Основные свойства загрязнителей воздушной средь

\begin{tabular}{|c|c|c|c|c|c|}
\hline $\begin{array}{c}\text { Наименование } \\
\text { компонента-загрязнителя } \\
\text { и его химическая формула }\end{array}$ & $\begin{array}{c}\text { Основные физико- } \\
\text { химические и } \\
\text { другие свойства }\end{array}$ & $\begin{array}{c}\text { Основные } \\
\text { источники } \\
\text { поступления в } \\
\text { атмосферу }\end{array}$ & 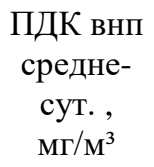 & $\begin{array}{c}\text { ПДК внп } \\
\text { макс. } \\
\text { раз., } \\
\text { мг/м³ }\end{array}$ & $\begin{array}{l}\text { Класс } \\
\text { опас- } \\
\text { ности }\end{array}$ \\
\hline $\begin{array}{c}\text { Оксид азота (IV) } \\
\text { (диоксид азота),NO2 }\end{array}$ & $\begin{array}{c}\text { Желтовато-бурый } \\
\text { газ с характерным } \\
\text { запахом, раздражает } \\
\text { дыхательные пути. } \\
\text { Активно } \\
\text { взаимодействует с } \\
\text { другими } \\
\text { загрязнителями } \\
\text { воздуха }\end{array}$ & $\begin{array}{c}\text { Выхлопные газы } \\
\text { автотранспорта, } \\
\text { продукты } \\
\text { сгорания топлив, } \\
\text { мусора и т.п. }\end{array}$ & 0,04 & 0,085 & 2 \\
\hline
\end{tabular}

\section{Вывод.}

\section{Рефлексия (5 минуты)}

Учитель: Ребята! Закончите три фразы: Сегодня на уроке я узнал ...Теперь я могу ...Было интересно ...Было трудно...

$$
* * *
$$

1. Винокурова Н.В. Глобальная экология: учеб. для 10-11 кл. профил. шк./Н.В. Винокурова, В.В. Трушин.-М.: Просвещение, 1998.-270с.

2. Жигарев И.А.Основы экологии: сборник задач, упражнений и практических работ к учебнику под редакцией Н.М. Черновой «Основы экологии.10(11) класс»/И.А. Жигарев, О.Н. Пономарева,Н.М. Чернова.-М.; Дрофа,2002.-208c.

3. Лященко О.А. Биоиндикация и биотестирование в охране окружающей среды [Текст]: учеб. пособ. / СПб ГТУРП. - СПб., 2012. - 67 с.

4. Шуралев, Э.А. Методы биоиндикации [Текст]: учебно-методическое пособие / М.Н. Мукминов, Э.А. Шуралев. - Казань: Казанский университет, 2011. - 9 с.

5. Интернет https://урок.pф/library/urok 81 prakticheskaya rabota 4 otcenka ekologi_092724.html (Дата обращения: 04.02.20).

Зарапина И.В., Осетров А.Ю., Щедрина М.В., Франк А.А., Толмачев А.В. Определение констант кислотности катиона пиридиния в этиленгликолевых и водно-этиленгликолевых средах методом предельных катодных токов

Тамбовский государственный технический университет

doi: $10.18411 / \mathrm{j}-05-2020-334$

(Россия, Тамбов)

idsp: ljournal-05-2020-334

\section{Аннотация}

Определены константы кислотности катиона $\mathrm{C}_{5} \mathrm{H}_{5} \mathrm{NH}^{+}$в этиленгликолевых растворах с содержанием воды 0,1 и 50 мас. \%. Показано, что эти величины в водных и этиленгликолевых растворах близки.

Ключевые слова: константа кислотности, вода, этиленгликоль, пиридин, железо. 